\title{
Non-steroidal Anti-inflammatory Drug Use and Risk of Age-Related Macular Degeneration in the California Teachers Study
}

\author{
Xiaoqing $\mathrm{Xu}^{1} \cdot$ Beate Ritz ${ }^{1} \cdot$ Anne L. Coleman ${ }^{1,2} \cdot$ Zeyan Liew $^{1} \cdot$ Dennis Deapen ${ }^{3} \cdot$ Eunjung Lee $^{3} \cdot$ Leslie Bernstein $^{4}$. \\ Rich Pinder ${ }^{3} \cdot$ Sarah F. Marshall ${ }^{3}$. Julia E. Heck ${ }^{1,5}$
}

Accepted: 20 June 2021 / Published online: 26 July 2021

(c) The Author(s) 2021

\begin{abstract}
Purpose The aim of this study was to examine whether use of regular aspirin and/or other non-steroidal anti-inflammatory drugs (NSAIDs) is associated with the development of age-related macular degeneration (AMD).

Methods In the California Teachers Study cohort $(N=88,481)$ we identified diagnoses of AMD up to December 31, 2012 by linkage to statewide hospital discharge records. Aspirin, ibuprofen, other NSAIDs, and acetaminophen use and comprehensive risk factor information were collected via self-administered questionnaires at baseline in 1995-1996 and a follow-up questionnaire in 2005-2006. We employed Cox proportional hazard regression to model AMD risk.

Results We did not find any associations between AMD and frequency and duration of aspirin or ibuprofen use reported at baseline. In the subsample with more specific information on medication use, we observed a $20 \%$ decrease in risk of AMD among low-dose aspirin users (HR 0.81, 95\% CI 0.70-0.95) and a 55\% decrease among cyclooxygenase-2 (COX-2) inhibitor users (HR 0.45 , 95\% CI 0.26-0.78) during 6.3 years of average follow-up.

Conclusion The decrease in risk of intermediate- or late-stage AMD among women who reported regular use of low-dose aspirin or specific COX-2 inhibitors suggests a possible protective role for medications with COX-2 inhibitory properties or aspirin at doses used for cardiovascular disease prevention.
\end{abstract}

Julia E. Heck

julia.heck@unt.edu

1 Department of Epidemiology, Fielding School of Public Health, UCLA, Los Angeles, CA, USA

2 Jules Stein Eye Institute, David Geffen School of Medicine, UCLA, Los Angeles, CA, USA

3 Department of Preventative Medicine, University of Southern California (USC) Keck School of Medicine, Los Angeles, CA, USA

4 Division of Biomarkers of Early Detection and Prevention, Department of Population Sciences, City of Hope National Medical Center and Comprehensive Cancer Center, Los Angeles, CA, USA

5 College of Health and Public Service, University of North Texas, 1155 Union Circle \#311340, Denton, TX 76203-5017, USA

\section{Key Points}

Age-related macular degeneration (AMD) was not related to duration or use of (full-dose) aspirin or ibuprofen at the start of the study.

Participants who took cyclooxygenase-2 (COX-2) inhibitors had a 55\% decrease in AMD risk, and low-dose aspirin users had a $20 \%$ decreased risk of AMD, across 6 years of follow-up.

\section{Introduction}

Following cataract and glaucoma, age-related macular degeneration (AMD) is the third leading cause of blindness worldwide, and is associated with decreased quality of life and increased dependence on caregivers [1, 2]. Early-stage AMD is usually asymptomatic and can develop 
into one of two forms, considered late-stage AMD: (1) geographic atrophy (dry form) and (2) neovascular AMD (wet-AMD) [2, 3]. In the US, $6.5 \%$ of the population over age 40 years has AMD at any point in time. For late-stage disease, the prevalence is $1.5 \%$ and this is projected to increase dramatically as the nation's 65 -and-older population grows [3].

Inflammation is proven to be a key component of drusen biogenesis, a significant pathogenic factor for both forms of AMD [4]. Cyclooxygenase-2 (COX-2), an inducible enzyme involved in the process of inflammation, is highly expressed in choroidal neovascular membranes in wetAMD patients [5]. These findings warrant research on a putative beneficial effect that anti-COX-2 medications may have for AMD. Aspirin and other nonsteroidal antiinflammatory drugs (NSAIDs) inhibit COX enzymes and may also have the potential to prevent the development of AMD. Moreover, low-dose (baby) aspirin is widely used for its antithrombotic properties in the primary and secondary prevention of cardiovascular diseases, such as heart attack and stroke, both of which are clinical risk factors for AMD [6-10].

Except for aspirin, few previous studies examined associations between specific types of NSAIDs and AMD and conflicting results have been reported on aspirin [11-16]. Though inverse associations between long-term low-dose aspirin use and AMD were reported in clinical trials [14, 15], large cohort studies concluded that long-term aspirin users had a 2-2.5 times increased risk for developing wetAMD, and this raised concern about the side effects of aspirin's anti-platelet property [11, 12]. Long-term aspirin use may affect AMD through three mechanisms: (1) reduced neovascularization through COX-2 inhibition; (2) reduced development of AMD through its cardioprotective effects; or (3) neovascularization stimulation at the retina as a result of aspirin's inhibition of platelet-mediated release of vascular endothelial growth factor (VEGF) and subsequently induced hypoxia. Non-aspirin NSAIDs are thought to affect AMD through the first mechanism only.

The primary aim of our study is to assess associations between long-term use of NSAIDs and AMD in a cohort of California teachers who were followed for up to 17 years, accounting for frequency, duration, and co-medication use. Since acetaminophen is the most common pain medication used for similar indications as aspirin and other NSAIDs, such as managing musculoskeletal pain and chronic headaches, but does not have anti-inflammatory or cardioprotective properties, here we used acetaminophen as a negative control to assess bias by indication.

\section{Materials and Methods}

A detailed description of the California Teachers Study (CTS) and its data has been published [17, 18]. Briefly, a prospective cohort of 133,477 female California teachers who completed a baseline self-administered questionnaire in 1995-1996 were followed both actively and passively with annual linkage to the California Office of Statewide Health Planning and Development (OSHPD) hospital discharge records and to state-wide death records. (Note: two participants who withdrew their consent to participate in CTS have been excluded from analyses.)

With institutional review board (IRB) approval, we generated a linked hospital, vital status, and baseline questionnaire dataset for each CTS participant [19]. Eligibility was limited to women who were California residents at baseline and had at least one OSHPD record available through 31 December $2012(N=89,877)$. Participants who had AMD prior to completing the baseline questionnaire $(n=22)$ and those who did not report their regular analgesic medication use $(n=1347)$ were excluded, leaving 88,481 participants for baseline analysis. After excluding women who developed AMD before 2005 or did not return this questionnaire, 50,202 subjects were eligible for the subsample analyses.

The first AMD event was identified from OSHPD hospital discharge data, which captured up to 25 diagnoses and the date of service at the visit. According to the guideline for secondary diagnoses in hospitals [20], only co-existing conditions that affect current treatments should be recorded. Thus, we assumed that the majority of AMD cases identified in this manner were intermediate to advanced and had impaired central vision, because these patients are more likely to require additional therapeutic procedures, increased nursing care, and have an extended length of stay [21]. In contrast, patients with early-stage AMD do not meet the criteria for a comorbid disorder relevant to current treatment and care during hospitalization; thus, we most likely did not capture as many of these with our passive linkage to hospital discharge records.

Follow-up started the day the baseline questionnaire was completed and ended at the earliest occurrence of one of the following four events: (1) AMD diagnosis; (2) moving out of California; (3) death; (4) date of the administrative censoring for this analysis (December 31, 2012).

At baseline, participants reported regular medication use (at least once per week), average frequency of use, and total years of use. Regular aspirin, acetaminophen, and ibuprofen consumption were asked about separately. More detailed 
Table 1 Demographic characteristics and lifestyle factors of study population at baseline in the California Teachers Cohort, 1995-2012 $(N=88,481)$

\begin{tabular}{|c|c|c|}
\hline Characteristics & All participants & AMD cases \\
\hline Total & $88,481(100 \%)$ & $1762(100 \%)$ \\
\hline \multicolumn{3}{|l|}{ Age (years) } \\
\hline$<50$ & $35,500(40.1 \%)$ & $53(3.0 \%)$ \\
\hline $51-60$ & $19,916(22.5 \%)$ & $143(8.0 \%)$ \\
\hline $61-70$ & $16,571(18.7 \%)$ & $498(28.3 \%)$ \\
\hline $71-80$ & $11,825(13.4 \%)$ & $743(42.2 \%)$ \\
\hline$>80$ & $4669(5.3 \%)$ & $325(18.4 \%)$ \\
\hline \multicolumn{3}{|l|}{ Race/ethnicity } \\
\hline Non-Latina White & $77,079(87.9 \%)$ & $1662(95.1 \%)$ \\
\hline African American & $2260(2.6 \%)$ & $24(1.4 \%)$ \\
\hline Native American & $3709(4.2 \%)$ & $20(1.1 \%)$ \\
\hline Latina & $829(0.9 \%)$ & $21(1.2 \%)$ \\
\hline Asian/Pacific Islander & $2796(3.2 \%)$ & $12(0.7 \%)$ \\
\hline Other & $1048(1.2 \%)$ & $8(0.5 \%)$ \\
\hline Missing & 760 & 15 \\
\hline \multicolumn{3}{|l|}{ BMI } \\
\hline Underweight & $2276(2.7 \%)$ & $40(2.5 \%)$ \\
\hline Normal & $47,374(56.1 \%)$ & $495(49.7 \%)$ \\
\hline Overweight & $21,831(25.8 \%)$ & $525(32.9 \%)$ \\
\hline Obese & $13,012(15.4 \%)$ & $238(14.9 \%)$ \\
\hline Unknown & 3988 & 164 \\
\hline \multicolumn{3}{|c|}{ History of high blood pressure } \\
\hline No & $70,874(80.1 \%)$ & $1140(64.7 \%)$ \\
\hline Yes & $17,607(19.9 \%)$ & $622(35.3 \%)$ \\
\hline \multicolumn{3}{|l|}{ History of heart attack/MI } \\
\hline No & $87,035(98.4 \%)$ & $1707(96.9 \%)$ \\
\hline Yes & $1446(1.6 \%)$ & $55(3.1 \%)$ \\
\hline \multicolumn{3}{|l|}{ History of stroke } \\
\hline No & $87,189(98.5 \%)$ & $1725(97.9 \%)$ \\
\hline Yes & $1292(1.5 \%)$ & $37(2.1 \%)$ \\
\hline \multicolumn{3}{|l|}{ History of diabetes mellitus } \\
\hline No & $85,492(96.6 \%)$ & $1659(94.2 \%)$ \\
\hline Yes & $2989(3.4 \%)$ & $103(5.8 \%)$ \\
\hline \multicolumn{3}{|l|}{ Smoking } \\
\hline Never & $16,782(19.2 \%)$ & $270(15.5 \%)$ \\
\hline Passive & $40,368(46.1 \%)$ & $735(42.2 \%)$ \\
\hline Former & $25,751(29.4 \%)$ & $642(36.8 \%)$ \\
\hline Current & $4590(5.2 \%)$ & $96(5.5 \%)$ \\
\hline Missing & 990 & 19 \\
\hline \multicolumn{3}{|l|}{ No. of smoking pack-years } \\
\hline Never or passive smoker & $57,150(67.4 \%)$ & $1005(59.9 \%)$ \\
\hline$\leq 10$ & $14,052(16.6 \%)$ & $246(14.7 \%)$ \\
\hline $11-20$ & $5187(6.1 \%)$ & $126(7.5 \%)$ \\
\hline$\geq 20$ & $8464(10.0 \%)$ & $301(17.9 \%)$ \\
\hline Missing & 3628 & 84 \\
\hline \multicolumn{3}{|l|}{ Daily alcohol intake (g) } \\
\hline None & $29,086(34.9 \%)$ & $578(35.1 \%)$ \\
\hline$<20$ & $47,340(56.7 \%)$ & $898(54.5 \%)$ \\
\hline
\end{tabular}

Table 1 (continued)

\begin{tabular}{lll}
\hline Characteristics & All participants & AMD cases \\
\hline$\geq 20$ & $7015(8.4 \%)$ & $173(10.5 \%)$ \\
Unknown & 5040 & 113 \\
Lifetime moderate and strenuous & physical activity $(\mathrm{h} /$ week) \\
$<2$ & $29,272(33.3 \%)$ & $804(46 \%)$ \\
$2-4$ & $21,822(24.8 \%)$ & $386(22.1 \%)$ \\
4 to $<6$ & $14,426(16.4 \%)$ & $240(13.7 \%)$ \\
$\geq 6$ & $22,319(25.4 \%)$ & $317(18.1 \%)$ \\
Unknown & 642 & 15 \\
\hline
\end{tabular}

$A M D$ age-related macular degeneration, $B M I$ body mass index, $M I$ myocardial infarction

NSAIDs use was recorded in a subsequent questionnaire mailed to cohort members in 2005: 'baby' or low-dose aspirin, aspirin, acetaminophen, ibuprofen, COX-2 inhibitors, and other NSAIDs. To better evaluate any possible role of confounding by indication, we examined acetaminophen as a negative control.

Potential confounder information was identified from questionnaire data or OSHPD hospital discharge records and selected based on the literature on AMD [3, 22]. We included in our models sociodemographic factors, lifestyle risk factors, and indications and contraindications for aspirin and other NSAIDs that may also affect AMD risk (Appendix $1)$.

\subsection{Statistical Analysis}

Multivariable Cox proportional hazards regression was used to assess the association between NSAIDs use and AMD. We examined the baseline analgesics in categories of frequency and duration of use, and tested for trend using category midpoints. To account for potential effects from use of other classes of analgesics, we calculated the approximate intensity of each of the three medications by multiplying the average frequency and total years of use and mutually adjusting in our models for these variables. The proportional hazards assumption was checked using Kaplan-Meier survival curves and graphs of the $\log (-\log$ (survival)) versus log of survival time; parallel lines indicated proportionality of hazards [23]. Cox proportional hazard regression with inverse probability weighting methods [24] was applied in subsample analyses that relied on the 2005 questionnaire information.

We performed sensitivity analyses by excluding women who had the first AMD diagnosis within the first 2 or 5 years of follow-up in the primary cohort and 2 years only in the subsample from 2005 onward to exclude prevalent AMD cases, and the exclusion did not change our results more 
than minimally; thus, we report results for the entire cohort without any exclusion.

To account for possible selection bias due to only including women with at least one OSHPD record available through December 31, 2012 (72\% of eligible CTS subjects), we also conducted additional sensitivity analyses weighing the data in the Cox models by the inverse probability of selection (Appendix 1). All analyses were performed using SAS Version 9.4 (SAS Institute, Cary, NC, USA).

\section{Results}

Among 88,481 CTS participants, we identified 1762 subjects with AMD. During an average of 14.8 years followup, $6598(7.5 \%)$ women moved out of California for a period of $>1$ year and 16,444 (18.6\%) died, leaving 63,677 (72\%) subjects who were right censored at end of followup (December 31, 2012). The median time to first AMD diagnosis was 13.5 years (interquartile range 10.2-15.5). The distribution of demographic and lifestyle factors for the study population and AMD cases are presented in Table 1. AMD frequency increased sharply with increasing age and was higher among Whites, overweight women, women who exercised little, and women with a self-reported history of medical conditions at baseline that are known to contribute to AMD. The current smoking rates were low in the cohort and comparable between AMD cases and controls, but total pack-years of smoking was higher among AMD cases. A similar proportion of women drank alcohol, but heavier drinkers were more common among AMD cases. Analgesic consumption in relation to demographic characteristics and health-related factors in the CTS has been previously described [23, 25].

Regular aspirin users were more likely to take these medications for more days per week and a higher proportion were long term ( $\geq 5$ years) compared with ibuprofen and acetaminophen users (Table 2). The hazard ratio for AMD was $>1$ for most of the use categories of aspirin and

Table 2 Self-reported use of NSAIDs and acetaminophen at baseline and age-related macular degeneration by frequency and duration of use in California Teachers Cohort, 1995-2012 $(N=88,481)$

\begin{tabular}{|c|c|c|c|c|c|c|c|c|c|}
\hline \multirow{2}{*}{$\begin{array}{l}\text { Frequency } \\
\text { and duration } \\
\text { of analgesics } \\
\text { use }\end{array}$} & \multicolumn{3}{|l|}{ Aspirin } & \multicolumn{3}{|l|}{ Ibuprofen } & \multicolumn{3}{|c|}{ Acetaminophen } \\
\hline & $\begin{array}{l}\text { No. of par- } \\
\text { ticipants }\end{array}$ & $\begin{array}{l}\text { No. of } \\
\text { AMD }\end{array}$ & $\begin{array}{l}\text { Adjusted- } \\
\text { HR (95\% } \\
\text { CI })^{\mathrm{a}}\end{array}$ & $\begin{array}{l}\text { No. of par- } \\
\text { ticipants }\end{array}$ & $\begin{array}{l}\text { No. of } \\
\text { AMD }\end{array}$ & $\begin{array}{l}\text { Adjusted- } \\
\text { HR (95\% } \\
\text { CI })^{\mathrm{a}}\end{array}$ & $\begin{array}{l}\text { No. of par- } \\
\text { ticipants }\end{array}$ & $\begin{array}{l}\text { No. of } \\
\text { AMD }\end{array}$ & $\begin{array}{l}\text { Adjusted-HR } \\
(95 \% \mathrm{CI})^{\mathrm{a}}\end{array}$ \\
\hline \multicolumn{10}{|c|}{ Frequency of regular use (days/week) } \\
\hline None & $\begin{array}{l}67,269 \\
(76.6 \%)\end{array}$ & $\begin{array}{l}1194 \\
\quad(68.5 \%)\end{array}$ & 1.00 (Ref.) & $\begin{array}{l}70,146 \\
(80.3 \%)\end{array}$ & $\begin{array}{l}1428 \\
(82.5 \%)\end{array}$ & 1.00 (Ref.) & $\begin{array}{l}76,082 \\
(86.7 \%)\end{array}$ & $\begin{array}{l}1532 \\
\quad(87.7 \%)\end{array}$ & 1.00 (Ref.) \\
\hline $1-3$ & $\begin{array}{l}9539 \\
(10.9 \%)\end{array}$ & $171(9.8 \%)$ & $\begin{array}{l}1.20(0.93- \\
1.55)\end{array}$ & $\begin{array}{l}9241 \\
\quad(10.6 \%)\end{array}$ & $93(5.4 \%)$ & $\begin{array}{l}0.97(0.72- \\
1.31)\end{array}$ & $8130(9.3 \%)$ & $111(6.3 \%)$ & $\begin{array}{l}1.21(0.85- \\
1.73)\end{array}$ \\
\hline$>3$ & $\begin{array}{l}11,011 \\
\quad(12.5 \%)\end{array}$ & $378(21.7 \%)$ & $\begin{array}{l}1.16(0.95- \\
1.41)\end{array}$ & $7945(9.1 \%)$ & $209(12.1 \%)$ & $\begin{array}{l}1.17(0.94- \\
1.45)\end{array}$ & $3513(4.0 \%)$ & $104(5.9 \%)$ & $\begin{array}{l}1.29(0.94- \\
1.78)\end{array}$ \\
\hline$p$ Trend & & & 0.48 & & & 0.22 & & & 0.69 \\
\hline \multicolumn{10}{|c|}{ Duration of regular use (year) } \\
\hline Never & $\begin{array}{l}67,269 \\
(76.6 \%)\end{array}$ & $\begin{array}{l}1194 \\
\quad(68.4 \%)\end{array}$ & 1.00 (Ref.) & $\begin{array}{l}70,146 \\
(79.5 \%)\end{array}$ & $\begin{array}{l}1428 \\
(81.3 \%)\end{array}$ & 1.00 (Ref.) & $\begin{array}{l}76,082 \\
(86.7 \%)\end{array}$ & $\begin{array}{l}1532 \\
(87.5 \%)\end{array}$ & 1.00 (Ref.) \\
\hline$<1-2$ & $5270(6.0 \%)$ & $149(8.5 \%)$ & $\begin{array}{l}1.28(0.94- \\
1.73)\end{array}$ & $7932(9.0 \%)$ & $172(9.8 \%)$ & $\begin{array}{l}1.03(0.71- \\
1.48)\end{array}$ & $2908(3.3 \%)$ & $65(3.7 \%)$ & $\begin{array}{l}1.22(0.80- \\
1.86)\end{array}$ \\
\hline $3-4$ & $2796(3.2 \%)$ & $90(5.2 \%)$ & $\begin{array}{l}1.26(0.90- \\
1.76)\end{array}$ & $3920(4.4 \%)$ & $61(3.5 \%)$ & $\begin{array}{l}0.86(0.57- \\
1.31)\end{array}$ & $1672(1.9 \%)$ & $32(1.8 \%)$ & $\begin{array}{l}1.00(0.61- \\
1.66)\end{array}$ \\
\hline$\geq 5$ & $\begin{array}{l}12,650 \\
(14.4 \%)\end{array}$ & $312(17.9 \%)$ & $\begin{array}{l}1.22(0.96- \\
1.55)\end{array}$ & $6178(7.0 \%)$ & $95(5.4 \%)$ & $\begin{array}{l}1.01(0.69- \\
1.48)\end{array}$ & $7556(8.6 \%)$ & $121(6.9 \%)$ & $\begin{array}{l}1.08(0.77- \\
1.51)\end{array}$ \\
\hline$p$ Trend & & & 0.77 & & & 0.97 & & & 0.58 \\
\hline
\end{tabular}

$A M D$ age-related macular degeneration, $B M I$ body mass index, $C I$ confidence interval, $H R$ hazard ratio, NSAIDs non-steroidal anti-inflammatory drugs

${ }^{a}$ Multivariable-adjusted model adjusted for age, smoking, diabetes, race/ethnicity, BMI, physical activities, alcohol use, hospitalization due to musculoskeletal system and connective tissue disease, hospitalization due to circulatory disease, asthma, coagulation/hemorrhagic conditions, antihypertensive medications use, frequency/duration of the index medication, and mutually adjusted for frequency/duration of other classes of medication 
Table 3 Joint analysis of dose and duration of regular use of NSAIDs and acetaminophen at baseline and risk of age-related macular degeneration in California Teachers Cohort, 1995-2012 $(N=88,481)$

\begin{tabular}{|c|c|c|c|}
\hline \multirow[t]{2}{*}{ Frequency (times/week) } & \multicolumn{3}{|l|}{$\begin{array}{l}\text { No. of AMD } \\
\text { HR }(95 \% \text { CI) }\end{array}$} \\
\hline & Never used & $<5$ years $^{\mathrm{a}}$ & $\geq 5$ years $^{\mathrm{a}}$ \\
\hline \multicolumn{4}{|l|}{ Aspirin } \\
\hline None & 11941.00 (ref.) & & \\
\hline $1-3$ & & $491.23(0.90-1.67)$ & $1191.14(0.93-1,40)$ \\
\hline 4 or more & & $1821.14(0.96-1.35)$ & $1821.12(0.95-1.33)$ \\
\hline \multicolumn{4}{|l|}{ Ibuprofen } \\
\hline None & 14281.00 (ref.) & & \\
\hline $1-3$ & & $631.12(0.85-1.47)$ & $260.93(0.61-1.40)$ \\
\hline 4 or more & & $1411.16(0.96-1.39)$ & $661.23(0.95-1.60)$ \\
\hline \multicolumn{4}{|l|}{ Acetaminophen } \\
\hline None & 15321.00 (ref.) & & \\
\hline $1-3$ & & $421.23(0.87-1.74)$ & $631.07(0.81-1.42)$ \\
\hline 4 or more & & $461.19(0.88-1.62)$ & $521.24(0.91-1.69)$ \\
\hline
\end{tabular}

acetaminophen (1.00-1.29) but no trend was apparent for frequency or duration, while regular ibuprofen use was not associated with AMD. When we jointly examined frequency and duration of use, the highest intensity use ( $>3$ days per week for $>5$ years) for the three baseline analgesics did not increase the risk of AMD (Table 3).

For women in the 2005 subsample, the median time to diagnosis of AMD was 4.3 years (interquartile range 2.9-7.1). We estimated inverse hazard ratios for use of lowdose aspirin (HR 0.81, 95\% CI 0.70-0.95) and COX-2 inhibitors (HR 0.45, 95\% CI 0.26-0.78) (Table 4). The inverse associations between low-dose aspirin or COX-2 inhibitors and AMD were of stronger magnitude in older adult patients (age $>50$ years) in our data. Regular acetaminophen use was positively associated with AMD risk (HR 1.24, 95\% CI 1.06-1.45) after accounting for the intensity of previous analgesic use and concurrent use of other classes of antiinflammatory drugs or acetaminophen.

\section{Discussion}

In a prospective cohort of CTS participants followed on average for 14.8 years, regular consumption of aspirin or ibuprofen was not associated with increased risk of intermediate- or late-stage AMD. For the subsample of CTS participants who answered the 2005 questionnaire, low-dose aspirin was assessed separately from standard-dose, and we observed a $20 \%$ decrease in the risk of AMD among women who regularly used low-dose aspirin. A potential beneficial effect was also seen in women who used selective COX-2 inhibitors, in fact, their risk of developing AMD was 55\% lower.

Previous studies of aspirin use and AMD risk reported negative, null, as well as positive associations, possibly due to the lack of a uniform definition of AMD, heterogeneous patterns of anti-inflammatory medication use, different lengths of follow-up, different degrees of residual confounding, and possibly confounding by indication. Positive associations between aspirin use and wet AMD and a null association for geographic atrophy were seen in cross-sectional studies and prospective cohorts [11-13]. Long-term aspirin use reduces synthesis of prostacyclin and leads to hypoxia with subsequent stimulation of neovascularization in the retina [13]; however, these positive associations observed in prospective cohorts might also be due to selection bias from differential censoring by AMD status and aspirin use since these cohorts had high follow-up loss rates [11, 12]. The CTS follow-up we employed-OSHPD linkage-was passive in nature, thus making a selective loss to follow-up among users less likely. 
Table 4 Self-reported use of NSAIDs and acetaminophen in subsequent (2005) questionnaire and age-related macular degeneration in California Teachers Cohort, 2005-2012 $(N=50,202)$

\begin{tabular}{|c|c|c|}
\hline Regular medication use in 2005 & No. of participants & Multivariable adjusted-HR ${ }^{\mathrm{a}}$ \\
\hline \multicolumn{3}{|l|}{ ‘Baby’ or low-dose aspirin } \\
\hline No & $35,834(71.4 \%)$ & 1.00 (ref.) \\
\hline Yes & $14,368(28.6 \%)$ & $0.81(0.70-0.95)$ \\
\hline \multicolumn{3}{|l|}{ Aspirin } \\
\hline No & $43,594(86.9 \%)$ & 1.00 (ref.) \\
\hline Yes & $6596(13.1 \%)$ & $0.90(0.73-1.12)$ \\
\hline Unknown & 12 & \\
\hline \multicolumn{3}{|c|}{ Naproxen, ketoprofen or other NSAIDs } \\
\hline No & $45,265(90.2 \%)$ & 1.00 (ref.) \\
\hline Yes & $4933(9.8 \%)$ & $1.00(0.79-1.27)$ \\
\hline Unknown & 4 & \\
\hline \multicolumn{3}{|l|}{ Ibuprofen } \\
\hline No & $40,012(79.7 \%)$ & 1.00 (ref.) \\
\hline Yes & $10,184(20.3 \%)$ & $0.90(0.75-1.07)$ \\
\hline Unknown & 6 & \\
\hline \multicolumn{3}{|l|}{ COX-2 inhibitors } \\
\hline No & $48,302(96.2 \%)$ & 1.00 (ref.) \\
\hline Yes & $1897(3.8 \%)$ & $0.45(0.26-0.78)$ \\
\hline Unknown & 3 & \\
\hline \multicolumn{3}{|l|}{ Steroid } \\
\hline No & $42,859(87.7 \%)$ & 1.00 (ref.) \\
\hline Yes & $5993(12.3 \%)$ & $0.91(0.73-1.13)$ \\
\hline \multicolumn{3}{|l|}{ Unknown } \\
\hline \multicolumn{3}{|l|}{ Acetaminophen } \\
\hline No & $38,697(77.1 \%)$ & 1.00 (ref.) \\
\hline Yes & $11,504(22.9 \%)$ & $1.24(1.06-1.45)$ \\
\hline Unknown & 1 & \\
\hline
\end{tabular}

$B M I$ body mass index, COX-2 cyclooxygenase-2, HR hazard ratio, NSAIDs non-steroidal anti-inflammatory drugs

${ }^{a}$ Multivariable-adjusted model adjusted for updated age, smoking, diabetes, race/ethnicity, BMI, physical activities, alcohol use, hospitalization due to musculoskeletal system and connective tissue disease, hospitalization due to circulatory disease, asthma, coagulation/hemorrhagic conditions, antihypertensive medications use, previous analgesics use and mutually adjusted for other classes of medication

In contrast to these prospective cohort and cross-sectional studies, a clinical trial of female health professionals suggested a $20 \%$ decreased risk of AMD over 10 years following regular use of aspirin $100 \mathrm{mg}$ (on alternate days, i.e., $\sim 3$ days per week) to prevent cardiovascular diseases [15], which is consistent with our findings of a $20 \%$ risk reduction for 'baby' aspirin use. Another randomized clinical trial of physicians followed for 5 years reported a comparable size risk reduction [14]. The proposed mechanism for aspirin are its beneficial effects on cardiovascular disease and atherosclerosis, which are risk factors for AMD development $[3,26]$. Moreover, low-dose aspirin can up-regulate the production of a local endogenous anti-inflammatory mediator $[15,27]$. The inhibitive effects of aspirin on isoforms of the
COX enzymes are irreversible and non-selective. Aspirin exerts its anti-thrombotic function through the acetylation of COX-1, a constitutive enzyme that is responsible for platelet aggregation. Long-term suppression of platelet aggregation is thought to decrease the progression to atherosclerosis, a common etiologic factor for cardiovascular disease and AMD [28, 29]. Deactivation of COX-2 by aspirin, on the other hand, reduces the production of proinflammatory prostaglandins. Aspirin-triggered anti-inflammatory mediators have the potential to suppress drusen formation [30]. Another plausible biologic explanation is that the inhibition of COX-2 expression can regulate VEGF levels and prevent the development of neovascular AMD [5]. 
Previous observational studies of aspirin use and AMD risk did not distinguish between low- and standard-dose treatments [31]. In our study, dose information was not ascertained in the baseline questionnaire, but in 1995, regular aspirin users would have been taking a standard dose (325 $\mathrm{mg}$ ) rather than the cardioprotective low-dose aspirin $(81 \mathrm{mg})$ recommended in the early 2000s by the American Heart Association guidelines [32]. For baseline analgesic use, the hazard ratio $>1$ for AMD among regular acetaminophen users (the negative control group) implies that the underlying indications for analgesic use may contribute to increased AMD risk and it may explain the estimated hazard ratios $>1$ for aspirin and ibuprofen use at baseline as well. The discrepancy between our study's estimates for aspirin use in 1995 and in 2005 in addition to dose changes may also be due to residual confounding, shorter lengths of follow-up, or the shift in the age structure of the cohort. As discussed earlier, certain underlying conditions that necessitate analgesic use may have confounded the association between baseline aspirin use and AMD [22, 26, 33]. Moreover, a small group of women who were aspirin users in 1995 but had discontinued use in 2005-probably due to adverse effects [7]—were also at a higher risk of developing AMD compared with never users (Appendix 2).

Previous studies reported inconclusive findings for nonaspirin NSAID use and AMD but few had information about the types of NSAIDs participants used. No association was observed between self-reported regular non-aspirin NSAIDs use and the 5-year incidence of early- or late-stage AMD in two prospective cohort studies [34, 35]. In our 2005 subcohort analysis, a 55\% decreased risk of AMD was detected specifically for COX-2 inhibitors but not for ibuprofen or other NSAIDs. This finding is further supported by an animal study in which oral administration of selective COX-2 inhibitors suppressed retinal VEGF expression and vascular leakage [36]. Although we cannot preclude the possibility of existing early-stage AMD at the time of completing the 2005 questionnaire, it was unlikely that women would stop taking COX-2 inhibitors after developing early-stage disease since a previous large multicenter study of AMD indicated a potentially protective effect of non-aspirin NSAIDs use on the risk of progression to geographic atrophy though not neovascular AMD [37]. The biologic explanations of potentially beneficial effects for COX-2 inhibitors are similar to aspirin, except that non-aspirin NSAIDs do not have antithrombotic or cardioprotective effects.

Our study has several strengths. This prospective study with routine passive follow-up via administrative hospital records provides us with a long average follow-up time and precludes self-selection out of this cohort. The large number of AMD cases observed enabled us to investigate effects for individual medications by duration and frequency and account for concurrent use of other types of medication.
Furthermore, the mixed approach of data collection-selfreported medication use covered prescription and nonprescription anti-inflammatory medications and the use of OSHPD records-allowed us to examine a comprehensive set of potential confounding factors, including indications and contraindications for aspirin and other NSAIDs use. However, there are also several limitations, most notably the onset of early AMD could not be captured using the hospitalization records and the AMD cases identified using this data source cannot be used to estimate the incidence rate of the disease. On the other hand, we did not have to rely on self-reported diagnoses and any outcome misclassification would be expected to be non-differential. Moreover, we were not able to disentangle effects of medications on incident AMD from their effect on progression from early- to latestage AMD. However, in sensitivity analyses that excluded AMD cases within the first 2 or even 5 years of follow-up, effect estimates did not change more than minimally. A randomized clinical trial is in progress to examine the potential protective effects of aspirin on the incidence and progression of AMD and results are expected by 2021 [38]. Also, we were not able to separate geographic atrophy and neovascular AMD, which may have different pathophysiologies [39]. Third, our study may suffer from bias due to non-differential misclassification of frequency and duration of medication use. Also, we had limited information to evaluate cumulative dose-response patterns since participants may have changed the frequency of their medication use over time. Lastly, we cannot rule out the possibility that the inverse association between low-dose aspirin use was due to ophthalmologists' suggestion to avoid or discontinue regular use of aspirin to reduce AMD progression [40].

\section{Conclusions}

The risk of intermediate- or late-stage AMD among women who reported regularly taking low-dose aspirin or COX-2 inhibitors was reduced in the California Teachers Study. However, standard-dose aspirin use and ibuprofen or other NSAIDs use was not protective. The elevated risk we also estimated for acetaminophen use, our negative control medication, suggests that these increased risk estimates might be due to confounding by indication. Future prospective studies of AMD and pain medications should evaluate the dosage, type, and timing of analgesic use [41].

\section{Appendix 1}

See Tables 5. 
Table 5 Demographic characteristics and lifestyle factors of participants at baseline in the California Teachers Cohort, 1995-2012 $(N=122,629)$

\begin{tabular}{|c|c|c|c|c|c|}
\hline Characteristics & $\begin{array}{l}\text { Participants with no } \\
\text { hospitalization data } \\
\text { (All CA residents) }\end{array}$ & $\begin{array}{l}\text { Study population (CA } \\
\text { resident with at least } 1 \\
\text { OSHPD record) }\end{array}$ & Age-adjusted HR & $\begin{array}{l}\text { Multivariable } \\
\text { adjusted-HR }\end{array}$ & $\begin{array}{l}\text { Multivariable adjusted- } \\
\text { HR weighted by } \\
1 / \mathrm{P}(\text { selection })^{\mathrm{b}}\end{array}$ \\
\hline Total & $34148(100 \%)$ & $88481(100 \%)$ & NA & NA & NA \\
\hline \multicolumn{6}{|l|}{ Age } \\
\hline$<50$ & $17615(51.6 \%)$ & $35500(40.1 \%)$ & 1.00 (ref.) & 1.00 (ref.) & 1.00 (ref.) \\
\hline $51-60$ & $10038(29.4 \%)$ & $19916(22.5 \%)$ & $5.11(3.73,7.00)$ & $4.30(3.07,6.01)$ & $4.30(3.11,5.94)$ \\
\hline $61-70$ & $3868(11.3 \%)$ & $16571(18.7 \%)$ & $23.70(17.86,31.46)$ & $19.60(14.50,26.55)$ & $20.05(14.92,26.93)$ \\
\hline $71-80$ & $1654(4.8 \%)$ & $11825(13.4 \%)$ & $71.80(54.33,94.90)$ & $57.22(42.39,77.24)$ & $58.46(43.60,78.39)$ \\
\hline$>80$ & $973(2.8 \%)$ & $4669(5.3 \%)$ & $\begin{array}{l}200.03(149.28 \\
268.02)\end{array}$ & $160(116.12,220.81)$ & $164(119.68,226.16)$ \\
\hline \multicolumn{6}{|l|}{ Race/ethnicity } \\
\hline Non-Latina White & $29157(86.2 \%)$ & $77079(87.9 \%)$ & 1.00 (ref.) & 1.00 (ref.) & 1.00 (ref.) \\
\hline African American & $991(2.9 \%)$ & $2260(2.6 \%)$ & $0.56(0.37,0.84)$ & $0.63(0.41,0.96)$ & $0.68(0.45,1.04)$ \\
\hline Native American & $1446(4.3 \%)$ & $3709(4.2 \%)$ & $0.66(0.42,1.03)$ & $0.61(0.36,1.01)$ & $0.58(0.34,1.00)$ \\
\hline Latina & $283(0.8 \%)$ & $829(0.9 \%)$ & $0.99(0.64,1.52)$ & $0.99(0.58,1.68)$ & $0.98(0.55,1.74)$ \\
\hline $\begin{array}{l}\text { Asian/Pacific } \\
\text { Islander }\end{array}$ & $1488(4.4 \%)$ & $2796(3.2 \%)$ & $0.31(0.18,0.55)$ & $0.24(0.12,0.49)$ & $0.27(0.13,0.53)$ \\
\hline Other & $468(1.4 \%)$ & $1048(1.2 \%)$ & $0.80(0.40,1.61)$ & $0.69(0.28,1.65)$ & $0.69(0.28,1.71)$ \\
\hline Missing & 315 & 760 & & & \\
\hline \multicolumn{6}{|l|}{ BMI } \\
\hline Underweight & $921(2.8 \%)$ & $2276(2.7 \%)$ & $1.25(0.91,1.71)$ & $1.12(0.78,1.61)$ & $1.12(0.77,1.65)$ \\
\hline Normal & $21056(63.9 \%)$ & $47374(56.1 \%)$ & 1.00 (ref.) & 1.00 (ref.) & 1.00 (ref.) \\
\hline Overweight & $7499(22.8 \%)$ & $21831(25.8 \%)$ & $1.18(1.05,1.31)$ & $1.14(1.01,1.28)$ & $1.16(1.02,1.31)$ \\
\hline Obese & $3484(10.6 \%)$ & $13012(15.4 \%)$ & $1.21(1.04,1.39)$ & $1.06(0.90,1.24)$ & $1.08(0.91,1.29)$ \\
\hline Unknown & 1188 & 3988 & & & \\
\hline \multicolumn{6}{|c|}{ History of high blood pressure } \\
\hline No & $30239(88.6 \%)$ & $70874(80.1 \%)$ & 1.00 (ref.) & 1.00 (ref.) & 1.00 (ref.) \\
\hline Yes & $3909(11.4 \%)$ & $17607(19.9 \%)$ & $1.25(1.13,1.38)$ & $1.17(0.97,1.40)$ & $1.16(0.96,1.42)$ \\
\hline \multicolumn{6}{|c|}{ History of heart attack/MI } \\
\hline No & $33961(99.5 \%)$ & $87035(98.4 \%)$ & 1.00 (ref.) & 1.00 (ref.) & 1.00 (ref.) \\
\hline Yes & $187(0.5 \%)$ & $1446(1.6 \%)$ & $1.14(0.87,1.50)$ & $1.05(0.77,1.42)$ & $1.05(0.75,1.49)$ \\
\hline \multicolumn{6}{|l|}{ History of stroke } \\
\hline No & $33874(99.2 \%)$ & $87189(98.5 \%)$ & 1.00 (ref.) & 1.00 (ref.) & 1.00 (ref.) \\
\hline Yes & $274(0.8 \%)$ & $1292(1.5 \%)$ & $1.02(0,74,1.42)$ & $0.95(0.66,1.36)$ & $0.95(0.63,1.41)$ \\
\hline \multicolumn{6}{|l|}{ History of diabetes } \\
\hline No & $33615(98.4 \%)$ & $85492(96.6 \%)$ & 1.00 (ref.) & 1.00 (ref.) & 1.00 (ref.) \\
\hline Yes & $533(1.6 \%)$ & $2989(3.4 \%)$ & $1.75(1.43,2.13)$ & $1.72(1.37,2.15)$ & $1.73(1.35,2.22)$ \\
\hline \multicolumn{6}{|l|}{ Smoking } \\
\hline Never & $6555(19.4 \%)$ & $16782(19.2 \%)$ & 1.00 (ref.) & 1.00 (ref.) & 1.00 (ref.) \\
\hline Passive & $16314(48.4 \%)$ & $40368(46.1 \%)$ & $0.95(0.82,1.09)$ & $0.98(0.84,1.15)$ & $0.99(0.84,1.17)$ \\
\hline Former & $9253(27.4 \%)$ & $25751(29.4 \%)$ & $1.16(1.01,1.34)$ & $1.16(0.99,1.37)$ & $1.16(0.97,1.38)$ \\
\hline Current & $1594(4.7 \%)$ & $4590(5.2 \%)$ & $1.41(1.12,1.78)$ & $1.31(1.00,1.71)$ & $1.33(0.99,1.79)$ \\
\hline Missing & 432 & 990 & & & \\
\hline \multicolumn{6}{|c|}{ No. of smoking pack-years } \\
\hline $\begin{array}{l}\text { Never or passive } \\
\text { smoker }\end{array}$ & $22869(69.9 \%)$ & $57150(67.4 \%)$ & 1.00 (ref.) & 1.00 (ref.) & 1.00 (ref.) \\
\hline$\leq 10$ & $5881(18 \%)$ & $14052(16.6 \%)$ & $1.00(0.87,1.15)$ & $0.99(0.86,1.23)$ & $1.00(0.85,1.18)$ \\
\hline $11-20$ & $1901(5.8 \%)$ & $5187(6.1 \%)$ & $1.14(0.95,1.37)$ & $1.09(0.88,1.33)$ & $1.10(0.88,1.37)$ \\
\hline$\geq 20$ & $2077(6.3 \%)$ & $8464(10 \%)$ & $1.62(1.42,1.84)$ & $1.50(1.30,1.73)$ & $1.50(1.28,1.76)$ \\
\hline Missing & 1420 & 3628 & & & \\
\hline
\end{tabular}


Table 5 (continued)

\begin{tabular}{|c|c|c|c|c|c|}
\hline Characteristics & $\begin{array}{l}\text { Participants with no } \\
\text { hospitalization data } \\
\text { (All CA residents) }\end{array}$ & $\begin{array}{l}\text { Study population (CA } \\
\text { resident with at least } 1 \\
\text { OSHPD record) }\end{array}$ & Age-adjusted HR & $\begin{array}{l}\text { Multivariable } \\
\text { adjusted-HR }^{\mathrm{a}}\end{array}$ & $\begin{array}{l}\text { Multivariable adjusted- } \\
\text { HR weighted by } \\
1 / \mathrm{P}(\text { selection })^{\mathrm{b}}\end{array}$ \\
\hline \multicolumn{6}{|c|}{ Daily alcohol intake (g) } \\
\hline None & $10188(31.3 \%)$ & $29086(34.9 \%)$ & 1.00 (ref.) & 1.00 (ref.) & 1.00 (ref.) \\
\hline$<20$ & $19700(60.5 \%)$ & $47340(56.7 \%)$ & $0.97(0.87,1.08)$ & $0.93(0.83,1.05)$ & $0.93(0.82,1.05)$ \\
\hline$\geq 20$ & $2651(8.1 \%)$ & $7015(8.4 \%)$ & $1.06(0.90,1.26)$ & $0.95(0.79,1.15)$ & $0.98(0.80,1.20)$ \\
\hline Unknown & 1609 & 5040 & & & \\
\hline \multicolumn{6}{|c|}{ Lifetime moderate and strenuous physical activity (h/week) } \\
\hline$<2$ & $10390(30.6 \%)$ & $29272(33.3 \%)$ & 1.00 (ref.) & 1.00 (ref.) & 1.00 (ref.) \\
\hline 2 to 4 & $9019(26.6 \%)$ & $21822(24.8 \%)$ & $0.93(0.82,1.05)$ & $0.91(0.79,1.04)$ & $0.91(0.78,1.04)$ \\
\hline 4 to $<6$ & $5853(17.3 \%)$ & $14426(16.4 \%)$ & $0.95(0.82,1.10)$ & $0.89(0.76,1.05)$ & $0.87(0.73,1.04)$ \\
\hline$\geq 6$ & $8667(25.5 \%)$ & $22319(25.4 \%)$ & $0.83(0.73,0.94)$ & $0.81(0.70,0.93)$ & $0.80(0.69,0.94)$ \\
\hline Unknown & & 642 & & & \\
\hline \multicolumn{6}{|l|}{ Aspirin use } \\
\hline No & $27464(80.4 \%)$ & $67269(76.0 \%)$ & 1.00 (ref.) & 1.00 (ref.) & 1.00 (ref.) \\
\hline Yes & $6684(19.6 \%)$ & $21212(24.0 \%)$ & $1.14(1.03,1.26)$ & $1.10(0.99,1.24)$ & $1.10(0.97,1.24)$ \\
\hline \multicolumn{6}{|l|}{ Ibuprofen use } \\
\hline No & $27991(82 \%)$ & $70146(79.3 \%)$ & 1.00 (ref.) & 1.00 (ref.) & 1.00 (ref.) \\
\hline Yes & $6157(18 \%)$ & $18335(20.7 \%)$ & $1.22(1.08,1.37)$ & $1.10(0.95,1.25)$ & $1.07(0.92,1.24)$ \\
\hline \multicolumn{6}{|l|}{ NSAIDs } \\
\hline No & $23617(69.2 \%)$ & $55967(63.2 \%)$ & 1.00 (ref.) & 1.00 (ref.) & 1.00 (ref.) \\
\hline Yes & $10530(30.8 \%)$ & $32514(36.7 \%)$ & $1.19(1.09,1.31)$ & $1.13(1.01,1.39)$ & $1.12(1.00,1.26)$ \\
\hline \multicolumn{6}{|c|}{ Acetaminophen use } \\
\hline No & $30253(88.6 \%)$ & $76082(86.0 \%)$ & 1.00 (ref.) & 1.00 (ref.) & 1.00 (ref.) \\
\hline Yes & $3895(11.4 \%)$ & $12399(14.0 \%)$ & $1.28(1.12,1.48)$ & $1.19(1.01,1.39)$ & $1.18(1.00,1.40)$ \\
\hline \multicolumn{6}{|c|}{ Antihypertensives } \\
\hline No & $30156(88.3 \%)$ & $77706(87.8 \%)$ & 1.00 (ref.) & 1.00 (ref.) & 1.00 (ref.) \\
\hline Yes & $3992(11.7 \%)$ & $10775(12.2 \%)$ & $1.25(1.14,1.38)$ & $1.03(0.86,1.23)$ & $1.02(0.84,1.25)$ \\
\hline
\end{tabular}

$B M I$ body mass index, $C A$ California, $H R$ hazard ratio, $M I$ myocardial infarction, NSAIDs non-steroidal anti-inflammatory drugs, $O S H P D$ California Office of Statewide Health Planning and Development

${ }^{a}$ Multivariable model adjusted for all variables listed in the table

${ }^{\mathrm{b}}$ Weighted multivariable model is weighted by the inverse probability of having at least one OSHPD records throughout the study period 


\section{Appendix 2}

See Table 6.

Table 6 Self-reported use of NSAIDs and acetaminophen and age-related macular degeneration stratified by time of initiation in California Teachers Cohort, 2005-2012 $(N=50,202)$

\begin{tabular}{|c|c|c|}
\hline & No. of participants & Adjusted-OR ${ }^{\mathrm{a}}(95 \% \mathrm{CI})$ \\
\hline \multicolumn{3}{|l|}{ Aspirin } \\
\hline No use at baseline or in 2005 & $22635(51.9 \%)$ & 1.00 (ref.) \\
\hline Use at baseline, no use in 2005 & $4446(10.2 \%)$ & $1.24(0.98,1.56)$ \\
\hline No use at baseline, use in 2005 & $10713(24.6 \%)$ & $0.98(0.83,1.17)$ \\
\hline Use at baseline and in 2005 & $5817(13.3 \%)$ & $0.86(0.70,1.07)$ \\
\hline \multicolumn{3}{|l|}{ Non-aspirin NSAIDs } \\
\hline No use at baseline or in 2005 & $2558(58.6 \%)$ & 1.00 (ref.) \\
\hline Use at baseline, no use in 2005 & $4363(10.0 \%)$ & $1.14(0.91,1.43)$ \\
\hline No use at baseline, use in 2005 & $8702(19.9 \%)$ & $0.84(0.69,1.03)$ \\
\hline Use at baseline and in 2005 & $4993(11.4 \%)$ & $0.87(0.66,1.15)$ \\
\hline \multicolumn{3}{|l|}{ Acetaminophen } \\
\hline No use at baseline or in 2005 & $30781(70.6 \%)$ & 1.00 (ref.) \\
\hline Use at baseline, no use in 2005 & $3174(7.3 \%)$ & $1.15(0.83,1.60)$ \\
\hline No use at baseline, use in 2005 & $6891(15.8 \%)$ & $1.15(0.96,1.37)$ \\
\hline Use at baseline and in 2005 & $2772(6.4 \%)$ & $1.50(1.13,1.96)$ \\
\hline
\end{tabular}

$C I$ confidence interval, NSAIDs non-steroidal anti-inflammatory drugs, $O R$ odds ratio

${ }^{a}$ Multivariable-adjusted model adjusted for age, smoking, diabetes, race/ethnicity, BMI, physical activities, alcohol use, hospitalization due to musculoskeletal system and connective tissue disease, hospitalization due to circulatory disease, asthma, coagulation/hemorrhagic conditions, antihypertensive medications use, frequency/duration of the index medication, and mutually adjusted for intensity of other classes of medication

Acknowledgements The authors would like to thank the California Teachers Study Steering Committee that is responsible for the formation and maintenance of the Study within which this research was conducted. A full list of California Teachers Study team members is available at https://www.calteachersstudy.org/team.

\section{Declarations}

Funding The California Teachers Study and the research reported in this publication were supported by the National Cancer Institute of the National Institutes of Health under award number U01-CA199277; P30-CA033572; P30-CA023100; UM1-CA164917; and R01-CA077398. The content is solely the responsibility of the authors and does not necessarily represent the official views of the National Cancer Institute or the National Institutes of Health.

Conflict of interest The authors have no conflicts of interest to report.

Ethical approval and consent This study was approved by Institutional Review Boards at the University of Southern California and the University of California, Los Angeles. Informed consent was collected prior to subjects' participation.
Data sharing The California Teachers Study may be contacted regarding data sharing.

Author contributions All authors contributed to the study conception and design. Data extraction and analysis was performed by XX, RP, and SM. Interpretation of results, writing and revising the manuscript: all authors.

Open Access This article is licensed under a Creative Commons Attribution-NonCommercial 4.0 International License, which permits any non-commercial use, sharing, adaptation, distribution and reproduction in any medium or format, as long as you give appropriate credit to the original author(s) and the source, provide a link to the Creative Commons licence, and indicate if changes were made. The images or other third party material in this article are included in the article's Creative Commons licence, unless indicated otherwise in a credit line to the material. If material is not included in the article's Creative Commons licence and your intended use is not permitted by statutory regulation or exceeds the permitted use, you will need to obtain permission directly from the copyright holder. To view a copy of this licence, visit http://creativecommons.org/licenses/by-nc/4.0/. 


\section{References}

1. Brown GC, Brown MM, Sharma S, Stein JD, Roth Z, Campanella $J$, et al. The burden of age-related macular degeneration: a value-based medicine analysis. Trans Am Ophthalmol Soc. 2005; 103:173.

2. Lim LS, Mitchell P, Seddon JM, Holz FG, Wong TY. Age-related macular degeneration. Lancet. 2012;379(9827):1728-38.

3. Velez-Montoya R, Oliver SCN, Olson JL, Fine SL, Quiroz-Mercado H, Mandava N. Current knowledge and trends in age-related macular degeneration: genetics, epidemiology, and prevention. Retina. 2014;34(3):423-41.

4. Anderson DH, Mullins RF, Hageman GS, Johnson LV. A role for local inflammation in the formation of drusen in the aging eye. Am J Ophthalmol. 2002;134(3):411-31.

5. Maloney SC, Fernandes BF, Castiglione E, Antecka E, Martins C, Marshall J-C, et al. Expression of cyclooxygenase-2 in choroidal neovascular membranes from age-related macular degeneration patients. Retina. 2009;29(2):176-80.

6. Curhan GC, Bullock AJ, Hankinson SE, Willett WC, Speizer FE, Stampfer MJ. Frequency of use of acetaminophen, nonsteroidal anti-inflammatory drugs, and aspirin in US women. Pharmacoepidemiol Drug Saf. 2002;11(8):687-93.

7. Carney RM, Freedland KE, Eisen SA, Rich MW, Skala JA, Jaffe AS. Adherence to a prophylactic medication regimen in patients with symptomatic versus asymptomatic ischemic heart disease. Behav Med. 1998;24(1):35-9.

8. O'Connor PJ, Pronk NP, Tan AW, Rush WA, Gray RJ. Does professional advice influence aspirin use to prevent heart disease in an HMO population. Eff Clin Pract. 1998;1(1):26-32.

9. Ajani UA, Ford ES, Greenland KJ, Giles WH, Mokdad AH. Aspirin use among US adults: behavioral risk factor surveillance system. Am J Prev Med. 2006;30(1):74-7.

10. Chakravarthy U, Wong TY, Fletcher A, Piault E, Evans C, Zlateva $\mathrm{G}$, et al. Clinical risk factors for age-related macular degeneration: a systematic review and meta-analysis. BMC Ophthalmol. 2010;10(1):31.

11. Liew G, Mitchell P, Wong TY, Rochtchina E, Wang JJ. The association of aspirin use with age-related macular degeneration. JAMA Intern Med. 2013;173(4):258-64.

12. Klein BEK, Howard KP, Gangnon RE, Dreyer JO, Lee KE, Klein $\mathrm{R}$. Long-term use of aspirin and age-related macular degeneration. JAMA. 2012;308(23):2469-78.

13. de Jong PTVM, Chakravarthy U, Rahu M, Seland J, Soubrane G, Topouzis F, et al. Associations between aspirin use and aging macula disorder: the European Eye Study. Ophthalmology. 2012;119(1):112-8.

14. Christen WG, Glynn RJ, Ajani UA, Schaumberg DA, Chew EY, Buring JE, et al. Age-related maculopathy in a randomized trial of low-dose aspirin among US physicians. Arch Ophthalmol. 2001;119(8):1143-9.

15. Christen WG, Glynn RJ, Chew EY, Buring JE. Low-dose aspirin and medical record-confirmed age-related macular degeneration in a randomized trial of women. Ophthalmology. 2009;116(12):2386-92.

16. Swanson MW, McGwin G Jr. Anti-inflammatory drug use and age-related macular degeneration. Optom Vis Sci. 2008;85(10):947-50.

17. Bernstein L, Allen M, Anton-Culver H, Deapen D, Horn-Ross PL, Peel D, et al. High breast cancer incidence rates among California teachers: results from the California Teachers Study (United States). Cancer Causes Control. 2002;13(7):625-35.

18. Duan L, Xu X, Koebnick C, Lacey JV, Sullivan-Halley J, Templeman $\mathrm{C}$, et al. Bilateral oophorectomy is not associated with increased mortality: the California Teachers Study. Fertil Steril. 2012;97(1):111-7.

19. Xu X, Ritz B, Coleman A, Liew Z, Deapen D, Lee E et al. Hypertension, antihypertensive medications use and risk of age-related macular degeneration in California Teachers Cohort. J Human Hypertens. 2020;34(8):568-76.

20. Foley SM, Daley J, Hughes J, Fisher ES, Heeren T. Comorbidities, complications, and coding bias: does the number of diagnosis codes matter in predicting in-hospital mortality? JAMA. 1992;267(16):2197-203.

21. Halpern MT, Schmier JK, Covert D, Venkataraman K. Resource utilization and costs of age-related macular degeneration. Health Care Financ Rev. 2006;27(3):37.

22. Age-Related Eye Disease Study Research G. Risk factors associated with age-related macular degeneration: a case-control study in the age-related eye disease study: age-related eye disease study report number 3. Ophthalmology. 2000;107(12):2224-32.

23. Marshall SF, Bernstein L, Anton-Culver H, Deapen D, Horn-Ross PL, Mohrenweiser $\mathrm{H}$, et al. Nonsteroidal anti-inflammatory drug use and breast cancer risk by stage and hormone receptor status. J Natl Cancer Inst. 2005;97(11):805-12.

24. Cole SR, Hernán MA. Constructing inverse probability weights for marginal structural models. Am J Epidemiol. 2008;168(6):656-64.

25. Zell JA, Ziogas A, Bernstein L, Clarke CA, Deapen D, Largent JA, et al. Nonsteroidal anti-inflammatory drugs. Cancer. 2009;115(24):5662-71.

26. Keenan TDL, Goldacre R, Goldacre MJ. Associations between age-related macular degeneration, osteoarthritis and rheumatoid arthritis: record linkage study. Retina. 2015;35(12):2613-8.

27. Machado FS, Johndrow JE, Esper L, Dias A, Bafica A, Serhan CN, et al. Anti-inflammatory actions of lipoxin A4 and aspirin-triggered lipoxin are SOCS-2 dependent. Nat Med. 2006;12(3):330-4.

28. Ridker PM, Manson JE, Buring JE, Goldhaber SZ, Hennekens $\mathrm{CH}$. The effect of chronic platelet inhibition with low-dose aspirin on atherosclerotic progression and acute thrombosis: clinical evidence from the Physicians' Health Study. Am Heart J. 1991;122(6):1588-92.

29. Vingerling JR, Dielemans I, Bots ML, Hofman A, Grobbee DE, de Jong PTVM. Age-related macular degeneration is associated with atherosclerosis the Rotterdam Study. Am J Epidemiol. 1995;142(4):404-9.

30. Nowak JZ. Aspirin and age-related macular degeneration: positives versus negatives. Routledge: Taylor \& Francis; 2014.

31. Zhu W, Wu Y, Xu D, Li Y-H, Jun B, Zhang X-L, et al. Aspirin use and risk of age-related macular degeneration: a meta-analysis. PLoS ONE. 2013;8(3):58821.

32. Pearson TA, Blair SN, Daniels SR, Eckel RH, Fair JM, Fortmann $\mathrm{SP}$, et al. AHA guidelines for primary prevention of cardiovascular disease and stroke: 2002 update. Circulation. 2002;106(3):388-91.

33. Michet Iii CJ, Achenbach SJ, Crowson CS, Matteson EL. Hospitalization rates and utilization among patients with giant cell arteritis: a population-based study from 1987 to 2012. Amsterdam: Elsevier; 2015.

34. Wang JJ, Mitchell P, Smith W, Gillies M, Billson F. Systemic use of anti-inflammatory medications and age-related maculopathy: the Blue Mountains Eye Study. Ophthalmic Epidemiol. 2003;10(1):37-48.

35. Klein R, Klein BK, Jensen SC, et al. Medication use and the 5-year incidence of early age-related maculopathy: the Beaver Dam Eye Study. Arch Ophthalmol. 2001;119(9):1354-9. https:// doi.org/10.1001/archopht.119.9.1354. 
36. Ayalasomayajula SP, Kompella UB. Celecoxib, a selective cyclooxygenase- 2 inhibitor, inhibits retinal vascular endothelial growth factor expression and vascular leakage in a streptozotocininduced diabetic rat model. Eur J Pharmacol. 2003;458(3):283-9.

37. Age-Related Eye Disease Study Research G. Risk factors for the incidence of advanced age-related macular degeneration in the Age-Related Eye Disease Study (AREDS): AREDS report no. 19. Ophthalmology. 2005;112(4):533-9.

38. Robman L, Guymer R, Woods R, Ward S, Wolfe R, Phung J, et al. Age-related macular degeneration in a randomized controlled trial of low-dose aspirin: rationale and study design of the ASPREEAMD study. Contemp Clin Trials Commun. 2017;6:105-14.
39. Kahawita SK, Casson RJ. Aspirin use and early age-related macular degeneration: a meta-analysis. Can J Ophthalmol J Can d'Ophtalmol. 2014;49(1):35-9.

40. Ying G-S, Maguire MG, Daniel E, Grunwald JE, Ahmed O, Martin DF, et al. Association between antiplatelet or anticoagulant drugs and retinal or subretinal hemorrhage in the comparison of age-related macular degeneration treatments trials. Ophthalmology. 2016;123(2):352-60.

41. Keller DL. Is $81-\mathrm{mg}$ aspirin associated with age-related macular degeneration risk. JAMA Intern Med. 2013;173(15):1476. 